\title{
Protein turnover rates of two human subjects during an unassisted crossing of Antarctica
}

\author{
BY M. A. STROUD AND A. A. JACKSON \\ Institute of Human Nutrition, West Wing Level C, Southampton General Hospital, Tremona Road, \\ Southampton SO9 $4 X Y$
}

AND J. C. WATERLOW

London School of Hygiene and Tropical Medicine, Keppel Street, London WC1E 7HT

(Received 31 October 1995 -Revised 12 April 1996 - Accepted 29 April 1996)

\begin{abstract}
During the Austral summer of 1992-3, two men, MS and RF, walked $2300 \mathrm{~km}$ across Antaretica in $96 \mathrm{~d}$, unassisted by other men, animals or machines. During the journey they ate freeze-dried rations, towed on sledges, that contained an average of $21.3 \mathrm{MJ} / \mathrm{d}$ of which $56.7 \%$ was fat, $35.5 \%$ carbohydrate and $\mathbf{7 . 8} \%$ protein $(98.8 \mathrm{~g})$. Despite this high energy intake both men lost more than $20 \mathrm{~kg}$ in body weight due to their extremely high energy expenditures. Studies of protein turnover using $\left[{ }^{15} \mathrm{~N}\right] \mathrm{glycine}$ by the singledose end-product method were made before, during and after the journey, and these demonstrated considerable differences in the metabolic responses of the two men to the combined stresses of exercise, cold and undernutrition. However, both men maintained high and relatively stable levels of protein synthesis during the expedition despite the great exertion and the onset of considerable debilitation. This stability indicates the vital physiological function of protein synthesis.
\end{abstract}

Protein turnover: Exercise: Undernutrition

During the Austral summer of 1992-3 two men made the first crossing of Antarctica, unassisted by other men, animals or machines. They travelled on foot, hauling sledges for 10-12 h every day. Each sledge had a starting weight of $222 \mathrm{~kg}$ and contained 100 days' supplies of food and fuel. The journey, which has been described by Stroud (1993), started at the Weddell Sea and ended after $96 \mathrm{~d}$ at the Ross ice-shelf. Overall, they covered about $2300 \mathrm{~km}$ with a climb of $3500 \mathrm{~m}$ to the highest part of the Antarctic polar plateau.

During the course of the journey the men consumed an average of $21.3 \mathrm{MJ} / \mathrm{d}$ which, in order to save weight, was derived mainly from fat. Based on measurements of energy expenditure made on an expedition of similar nature (Stroud, 1987) it was expected that loss of body weight would be limited to $10 \mathrm{~kg}$. In the event this was an underestimate and weight losses exceeded $20 \mathrm{~kg}$. At the end of the journey the two men were on half-rations.

In the course of the expedition a number of scientific studies were made including measurements of whole-body protein turnover, since little is known about the response of this key function to very severe exertion continued over a long time, especially when combined with negative energy balance. Protein turnover was measured 1 week before the expedition; five times during the expedition on days $9 / 10,19 / 20,49 / 50,76 / 77$, and $92 / 96$ (the two subjects being tested on different days); and twice following the journey, 2 and 3 weeks after return. The present paper reports the results of these measurements. 


\section{METHODS}

Subjects

The subjects, MS and RF, were fit men aged 37 and 48 years respectively. Both men gave informed written consent for all experiments.

\section{Energy intake}

Before and after the expedition normal foods were consumed ad libitum. The amount of each food was estimated and recorded, but not weighed. These semi-quantitative records were analysed independently by two dietitians.

During the expedition the subjects ate a specially formulated pre-packed diet (Be-Well Nutrition, Stamford, Lincs.) containing a high proportion of fat in order to provide a high energy: weight ratio. This consisted of freeze-dried meals supplemented with butter, chocolate bars, biscuits, soups and hot chocolate drinks. Breakfast, consisting of hot cereal and butter, was eaten at 07.30 hours; soup and chocolate bars were eaten at intervals throughout the day; and the main meal was taken at 21.00 hours. Analysis was performed before departure with food values taken from manufacturers' nutritional information about their products. All food was weighed and packaged into daily ration bags at the beginning of the expedition and, at the end of the expedition, mean daily energy intakes were calculated making an allowance for any unused food.

\section{Energy expenditure}

Mean daily energy expenditure was estimated for the first $50 \mathrm{~d}$ and the last $45 \mathrm{~d}$ of the expedition by combining mean dietary energy intakes with the mean daily energy deficits calculated from losses of lean tissues and fat over each period of the expedition.

Body masses were recorded in the UK (Salter KR120 scales, West Bromwich, East Midlands) before and after the expedition, and were also recorded at $10 \mathrm{~d}$ intervals during the journey with a miniature load-cell portable scale (Miniscale, Raviv-Aran, Israel). On each occasion the measurements were made after overnight fast, defaecation and the voiding of urine. Body composition estimates were calculated on days 0 and 50 of the expedition from the dilution space of the stable isotope ${ }^{18} \mathrm{O}$ and on day 95 of the expedition from the dilution space of ${ }^{2} \mathbf{H}$. These isotopes were given to the subjects in order to measure energy expenditure using the doubly-labelled water method, a study that is to be reported elsewhere (Stroud et al. 1996). Measurements of body composition were also made $10 \mathrm{~d}$ before and $7 \mathrm{~d}$ after the expedition using underwater weighing (UWW) with measurements of residual lung volumes by He-dilution spirometer (Gould Pulmonet III). Lean-tissue losses were assumed to be $73 \%$ water and $27 \%$ protein, whereas fat losses were considered to be $100 \%$ fat. The energy value of protein was taken as $18.39 \mathrm{~kJ} / \mathrm{g}$ and that of fat was taken as $39.7 \mathrm{~kJ} / \mathrm{g}$ (Brouwer, 1965).

\section{Protein turnover}

Protein turnover was measured with $\left[{ }^{15} \mathrm{~N}\right]$ glycine by the single-dose end-product method (Fern et al. 1981). The bladder was emptied at 07.00 hours and the subject then took $100 \mathrm{mg}\left[{ }^{15} \mathrm{~N}\right]$ glycine (Promochem, Welwyn Garden City, Herts.; 99 atom per cent ${ }^{15} \mathrm{~N}$ ) dissolved in water. Urine was collected in containers with thymol crystals as a preservative until 19.00 hours. A second urine collection was made from 19.00 hours to 07.00 hours the next morning. Urine volumes were measured and a sample retained for later analysis.

Urinary creatinine was determined by the Jaffre reaction and urinary $\mathrm{NH}_{3}$ and urea were measured by the Berthelot reaction. $\mathrm{NH}_{3}$ and urea- $\mathrm{N}$ were removed stepwise from urine 
samples for mass spectrometry. The amount of urine estimated to contain $2 \mathrm{mg} \mathrm{NH}_{3}-\mathrm{N}$ was made up to $14 \mathrm{ml}$ with water and $10 \mathrm{M}-\mathrm{NaOH}$ to adjust the $\mathrm{pH}$ to 11-12. This was then aerated into $15 \mathrm{ml}$ of $0.005 \mathrm{M}-\left(\mathrm{NH}_{4}\right)_{2} \mathrm{SO}_{4}$ for $3 \mathrm{~h}$ before $1-2 \mathrm{ml}$ was used for mass spectrometry. The volume of $\mathrm{NH}_{3}$-free urine estimated to contain $2 \mathrm{mg}$ urea-N was then treated with urease $(E C 3.5 .1 .5)$ at $\mathrm{pH} 7.8$ at $37^{\circ}$ for $3 \mathrm{~h}$ in EDTA buffer, before the resulting $\mathrm{NH}_{3}$ was collected by further alkaline aeration. The ${ }^{15} \mathrm{~N}$ abundances in the $\mathrm{NH}_{3}$ collections were measured in a triple collector mass spectrometer (SIRA 10; VG Isogas, Middlewich, Ches.) after liberation of $\mathrm{N}_{2}$ by LiOH.

In each test ${ }^{15} \mathrm{~N}$ abundances were calculated after subtracting the background abundance in the urine sample collected before the dose of labelled glycine. The flux $\mathrm{Q}$ was calculated from the general equation:

$$
\mathrm{Q}(\mathrm{gN} / 12 \mathrm{~h})=\mathrm{d} . \mathrm{E} / \mathrm{e},
$$

where $\mathrm{d}$ is the dose of ${ }^{15} \mathrm{~N}(\mathrm{mg})$ (Waterlow et al. 1978b).

For the flux based on $\mathrm{NH}_{3}\left(\mathrm{Q}_{\mathrm{A}}\right)$ :

and

$$
\mathrm{E}_{\mathrm{A}}(12)=\mathrm{NH}_{3}-\mathrm{N} \text { excreted in } 12 \mathrm{~h}(\mathrm{~g}) \text {, }
$$

$$
\mathrm{e}_{\mathrm{A}}(12)={ }^{15} \mathrm{~N} \text { excreted in } \mathrm{NH}_{3} \text { in } 12 \mathrm{~h}(\mathrm{mg}) \text {. }
$$

For the flux based on urea $\left(\mathrm{Q}_{\mathrm{U}}\right)$ :

$$
\mathrm{E}_{\mathrm{U}}(12)=\text { urea } \mathrm{N} \text { excreted in } 12 \mathrm{~h}(\mathrm{~g}) \text {. }
$$

Since blood samples were not taken, it was assumed that there was no significant change in the size of the body urea pool. The value of $e_{U}$, the isotope excreted in urea, needed to be corrected for the isotope retained as urea in the body at $12 \mathrm{~h}$. Since this could not be measured directly, it was assumed that all the labelled urea remaining in the body at $12 \mathrm{~h}$ had been excreted by $24 \mathrm{~h}$ (Grove \& Jackson, 1995). Therefore the appropriate value for $\mathrm{e}_{\mathrm{U}}$ is the ${ }^{15} \mathrm{~N}$ excreted in $24 \mathrm{~h}$. Hence

$$
\mathrm{Q}_{\mathrm{U}}(12)=\mathrm{d} . \mathrm{E}_{\mathrm{U}}(12) / \mathrm{e}_{\mathrm{U}}(24) .
$$

The error introduced by this assumption is considered later.

Rates of protein synthesis $(\mathrm{S})$ and breakdown $(\mathrm{B})$ were obtained from the usual equation:

$$
\mathrm{Q}=\mathrm{S}+\mathrm{E}=\mathrm{B}+\mathrm{I},
$$

where $I$ is the intake and $E$ is the total urinary $N$ excretion, for which $E_{U}+E_{A}+N$ loss in creatinine is taken as a proxy. Because the measurement of $Q_{A}$ is more open to error, synthesis rates were calculated only from $Q_{\mathrm{V}}$ and were determined only for the $12 \mathrm{~h}$ periods following the dose since it could not be assumed that rates of protein synthesis and breakdown remained the same during the night, when only one meal was eaten, as during the day, when the bulk of the food was consumed.

\section{RESULTS}

The dietary intake provided an average over the whole journey of $21.3 \mathrm{MJ} / \mathrm{d}$ of which $56.7 \%$ came from fat, $35.5 \%$ from carbohydrate and $7.8 \%$ from protein. Over the first $50 \mathrm{~d}$ the average daily intake was $19.9 \mathrm{MJ}$ consisting of $95 \mathrm{~g}$ protein, $293 \mathrm{~g}$ fat, and $425 \mathrm{~g}$ carbohydrate. Over the second part of the expedition the average daily intake was $22.2 \mathrm{MJ}$ consisting of $103 \mathrm{~g}$ protein, $338 \mathrm{~g}$ fat, and $557 \mathrm{~g}$ carbohydrate.

Despite the high energy intake, both men lost considerable weight and became significantly debilitated by starvation towards the end of the walk. In the later stages they also developed frostbite of the hands and feet which became chronically infected. The 
Table 1. Body weight and body composition of two men, before, during and after an unassisted crossing of Antarctica, measured using isotope dilution or underwater weighing

\begin{tabular}{|c|c|c|c|c|c|c|c|c|c|c|c|}
\hline \multirow[b]{2}{*}{ Subject } & \multirow[b]{2}{*}{$\begin{array}{c}\text { Age } \\
\text { (years) }\end{array}$} & \multicolumn{5}{|c|}{ Body weight (kg) } & \multicolumn{5}{|c|}{ Body fat (\%) } \\
\hline & & $\begin{array}{l}\text { Day } \\
-10\end{array}$ & $\begin{array}{c}\text { Day } \\
0\end{array}$ & $\begin{array}{c}\text { Day } \\
50\end{array}$ & $\begin{array}{c}\text { Day } \\
95\end{array}$ & $\begin{array}{l}\text { Day } \\
+7\end{array}$ & $\begin{array}{l}\text { Day } \\
-10^{*}\end{array}$ & $\begin{array}{c}\text { Day } \\
0\end{array}$ & $\begin{array}{c}\text { Day } \\
50\end{array}$ & $\begin{array}{c}\text { Day } \\
95\end{array}$ & $\begin{array}{l}\text { Day } \\
+7^{*}\end{array}$ \\
\hline MS & 37 & $69 \cdot 0$ & $74 \cdot 8$ & $59 \cdot 3$ & 53.0 & 58.8 & $16 \cdot 3$ & $22 \cdot 8$ & $8 \cdot 3$ & 0.0 & $2 \cdot 5$ \\
\hline RF & 48 & $89 \cdot 9$ & $95 \cdot 6$ & $72 \cdot 8$ & $71 \cdot 0$ & 76.2 & $17 \cdot 4$ & $22 \cdot 3$ & $2 \cdot 1$ & 0.0 & 1.9 \\
\hline
\end{tabular}

* Body fat determined using underwater weighing.

estimates of body composition from the stable isotopes and UWW are shown in Table 1. The isotope data indicated that MS lost $9.8 \mathrm{~kg}$ fat and $5.7 \mathrm{~kg}$ lean tissue during the first $50 \mathrm{~d}$, whereas RF lost $22.9 \mathrm{~kg}$ fat and actually gained $0.1 \mathrm{~kg}$ lean tissues. Similar differences were also seen during the latter $45 \mathrm{~d}$ of the expedition when MS lost $5.5 \mathrm{~kg}$ fat and $0.8 \mathrm{~kg}$ lean tissues, whereas RF lost $2.2 \mathrm{~kg}$ fat and gained $0.4 \mathrm{~kg}$ lean tissue. At the end of the expedition the isotope data in both men suggested that fat content was zero, although in both men the isotope dilution spaces were exceptionally large suggesting that there had been considerable increases in the water content of the lean body mass. The UWW values for body fat at $7 \mathrm{~d}$ post-expedition, after considerable food intake and weight gain, were also exceptionally low in both men and hence tend to support the fact that fat stores were essentially zero on the last day of the journey.

Combining the intake data with the estimated changes in body composition yielded energy expenditures during the first $50 \mathrm{~d}$ of $28.3 \mathrm{MJ} / \mathrm{d}$ in $\mathrm{MS}$ and $38.1 \mathrm{MJ} / \mathrm{d}$ in RF, whilst during the last $45 \mathrm{~d}$ they were $26.6 \mathrm{MJ} / \mathrm{d}$ in MS and $23.9 \mathrm{MJ} / \mathrm{d}$ in RF. These values for the first $50 \mathrm{~d}$ were similar to those estimated using isotope-labelled water which gave values of $29.1 \mathrm{MJ} / \mathrm{d}$ in $\mathrm{MS}$ and $35.5 \mathrm{MJ} / \mathrm{d}$ in RF. In the latter $45 \mathrm{~d}$ there was less good agreement with isotope values of $18.8 \mathrm{MJ} / \mathrm{d}$ in MS and 23.1 MJ/d for RF (Stroud et al. 1996).

Table 2 shows the timing of the protein turnover studies, and gives body weights and estimated energy and protein intakes at the time of each test. It also contains some general comments on the condition of the subjects and their situation at the time. As discussed in the Methods section, the pre- and post-expedition values are less accurate than those made during the expedition. Table 3 shows the $24 \mathrm{~h}$ urine volume, $\mathrm{N}$ intake, output and the apparent $\mathrm{N}$ balance, together with the output of creatinine. It also shows the percentages of the dose of ${ }^{15} \mathrm{~N}$ excreted in $\mathrm{NH}_{3}$ during the first $12 \mathrm{~h}$ and in urea from $0-12$ and from 12-24 h. If the urea pool turns over with a half-life of about $10 \mathrm{~h}$ (Waterlow et al. 1978a), it can be calculated that about $8 \%$ of the $\left[{ }^{15} \mathrm{~N}\right]$ urea formed will still be retained in the body at $24 \mathrm{~h}$. Fern et al. (1981), by direct measurement with $\left[{ }^{15} \mathrm{~N}\right]$ urea, obtained a value of $10 \%$ for retention at $24 \mathrm{~h}$ and so values of total $\left[{ }^{15} \mathrm{~N}\right]$ urea excreted, corrected by adding $10 \%$, are also shown in Table 3.

There were two cases in which excretion of $\left[{ }^{15} \mathrm{~N}\right]$ urea was suspiciously low in the period 0-12 h: MS4 and RF3. These results suggest that the urine collections were incomplete and the $\mathrm{NH}_{3}$ values bear this out. An incomplete collection, even if the loss is small, will be far more serious if urine is lost in the first few hours after the dose than if it is lost later on. In an attempt to clarify these possible losses, Table 3 also shows the excretion during the $12 \mathrm{~h}$ daytime period compared with that during the night $(\mathrm{D}: \mathrm{N})$ for a number of variables: $\mathrm{N}$, creatinine, ${ }^{15} \mathrm{~N}$ in urea $\left(\mathrm{e}_{\mathrm{U}}\right)$ and ${ }^{15} \mathrm{~N}$ in $\mathrm{NH}_{3}\left(\mathrm{e}_{\mathrm{A}}\right)$. The results suggests incomplete collection in MS4, RF3, and possibly MS7. The fact that some of the D:N ratios may be 
Table 2. Position, conditions and body weights of two men, MS and RF, before, during and after an unassisted crossing of Antarctica on test days with estimates of energy and protein intakes for 07.00-19.00 hours $(D), 19.00-07.00$ hours $(N)$ and total $24 \mathrm{~h}$ period $(T)$

\begin{tabular}{|c|c|c|c|c|c|c|c|c|c|}
\hline \multirow{2}{*}{$\begin{array}{l}\text { Test } \\
\text { no. }\end{array}$} & \multirow[b]{2}{*}{ Day* } & \multicolumn{3}{|c|}{$\begin{array}{l}\text { Body weight } \\
(\mathrm{kg})\end{array}$} & \multicolumn{2}{|c|}{$\begin{array}{l}\text { Energy intake } \\
\qquad(\mathrm{MJ} / \mathrm{d})\end{array}$} & \multicolumn{2}{|c|}{$\begin{array}{l}\text { Protein } \\
\text { intake } \\
(\mathrm{g} / \mathrm{d})\end{array}$} & \multirow[b]{2}{*}{ General conditions } \\
\hline & & MS & $\mathrm{RF}$ & & MS & RF & MS & RF & \\
\hline 0 & Pre 7 & $71 \cdot 7$ & $92 \cdot 0$ & $\mathbf{T}$ & $31 \cdot 04$ & $29 \cdot 59$ & 248 & 213 & Gaining weight before departure \\
\hline 1 & 9,10 & $72 \cdot 0$ & $95 \cdot 0$ & $\begin{array}{l}\mathbf{D} \\
\mathbf{N} \\
\mathbf{T}\end{array}$ & $\begin{array}{r}12 \cdot 25 \\
6 \cdot 60 \\
18 \cdot 85\end{array}$ & $\begin{array}{r}10 \cdot 95 \\
6 \cdot 60 \\
17 \cdot 56\end{array}$ & $\begin{array}{l}54 \\
34 \\
88\end{array}$ & $\begin{array}{l}50 \\
34 \\
84\end{array}$ & $\begin{array}{l}\text { Position - } 79 \text { deg } 37 \text { min South. Good } \\
\text { physical condition. Temperature }-15^{\circ}\end{array}$ \\
\hline 2 & 19,20 & $68 \cdot 8$ & $91 \cdot 5$ & $\begin{array}{l}\mathrm{D} \\
\mathrm{N} \\
\mathrm{T}\end{array}$ & $\begin{array}{r}12 \cdot 25 \\
5 \cdot 39 \\
17 \cdot 64\end{array}$ & $\begin{array}{r}11 \cdot 58 \\
6 \cdot 60 \\
18 \cdot 18\end{array}$ & $\begin{array}{l}54 \\
42 \\
96\end{array}$ & $\begin{array}{l}57 \\
34 \\
91\end{array}$ & $\begin{array}{l}\text { Position }-81 \text { deg } 37 \text { min South. Reached } \\
\text { land and beginning to climb. Onset of } \\
\text { extreme work. Temperature }-18^{\circ}\end{array}$ \\
\hline 3 & 49,50 & $59 \cdot 3$ & $72 \cdot 8$ & $\begin{array}{l}\mathrm{D} \\
\mathbf{N} \\
\mathbf{T}\end{array}$ & $\begin{array}{r}15 \cdot 22 \\
6 \cdot 27 \\
21 \cdot 49\end{array}$ & $\begin{array}{r}15 \cdot 22 \\
6 \cdot 65 \\
21 \cdot 86\end{array}$ & $\begin{array}{r}66 \\
34 \\
100\end{array}$ & $\begin{array}{l}66 \\
31 \\
97\end{array}$ & $\begin{array}{l}\text { Position - } 86 \text { deg } 58 \mathrm{~min} \text { South. Edge of } \\
\text { Polar plateau at } 8000 \text { feet. Marked } \\
\text { fatigue and onset of hunger. } \\
\text { Temperature }-28^{\circ}\end{array}$ \\
\hline 4 & 77,76 & $56 \cdot 3$ & $71 \cdot 1$ & $\begin{array}{l}\mathbf{D} \\
\mathrm{N} \\
\mathrm{T}\end{array}$ & $\begin{array}{r}17 \cdot 97 \\
8 \cdot 32 \\
26 \cdot 29\end{array}$ & $\begin{array}{r}17 \cdot 97 \\
8 \cdot 03 \\
26 \cdot 00\end{array}$ & $\begin{array}{r}76 \\
39 \\
115\end{array}$ & $\begin{array}{r}72 \\
49 \\
121\end{array}$ & $\begin{array}{l}\text { Position - } 87 \text { deg } 57 \text { min South. Beyond } \\
\text { Pole on plateau at } 12400 \text { feet. } \\
\text { Constantly cold and hungry. RF } \\
\text { frostbitten. Temperature }-48^{\circ}\end{array}$ \\
\hline 5 & 92,96 & $53 \cdot 3$ & $71 \cdot 0$ & $\begin{array}{l}\mathrm{D} \\
\mathrm{N} \\
\mathrm{T}\end{array}$ & $\begin{array}{r}9 \cdot 74 \\
4 \cdot 14 \\
13 \cdot 88\end{array}$ & $\begin{array}{r}9 \cdot 82 \\
3 \cdot 72 \\
13 \cdot 50\end{array}$ & $\begin{array}{l}39 \\
17 \\
56\end{array}$ & $\begin{array}{l}39 \\
17 \\
56\end{array}$ & $\begin{array}{l}\text { Position }-83 \mathrm{deg} 10 \mathrm{~min} \text { South. Back } \\
\text { down on Pacific ice-shelf. Episodic } \\
\text { hypoglycaemia, marked muscle pains. RF } \\
\text { and MS frostbitten. Temperature }-35^{\circ}\end{array}$ \\
\hline 6 & Post 14 & $58 \cdot 8$ & $76 \cdot 2$ & $\mathrm{~T}$ & $25 \cdot 42$ & $24 \cdot 49$ & 203 & 185 & Recovering in UK \\
\hline 7 & Post 20 & $61 \cdot 5$ & $78 \cdot 9$ & $\mathbf{T}$ & $22 \cdot 17$ & $26 \cdot 35$ & 144 & 162 & Recovering in UK \\
\hline
\end{tabular}

* The first number is for RF and the second for MS.

low when that for creatinine is not particularly reduced may be due to a small loss in an early urine specimen having a large effect on the isotope output, particularly in $e_{A}$, with little effect on creatinine.

The estimates of flux based on urea $\left(\mathrm{Q}_{U}\right)$ and $\mathrm{NH}_{3}\left(\mathrm{Q}_{\mathrm{A}}\right)$ are shown in Table 4 (with $\mathrm{Q}_{U}$ corrected for an estimated $10 \%$ retention of $e_{U}$ at $24 \mathrm{~h}$ ) along with synthesis rates derived from $Q_{U}$ by subtraction of the $12 \mathrm{~h} \mathrm{~N}$ output. High synthesis rates were maintained throughout the expedition by both men.

\section{DISCUSSION}

It is evident from the weight losses alone that this expedition entailed extremely hard work, maintained for a period of over 3 months. The first part of the journey involved climbing $3500 \mathrm{~m}$ and in many places the terrain was made difficult and dangerous by crevasses and ridges of iced snow. Both subjects at times experienced symptoms of hypoglycaemia and RF had severe frostbite of the feet, while MS had frostbitten fingers. At the end of the journey, by the time of test 5 (days 92 and 96), they had been on half rations for 8 (RF) and 12 (MS) d. When they reached the ice-shelf of Ross Bay, having successfully completed the crossing of the Antarctic continent, they were so exhausted that they would probably have died if they had tried to reach open water. 


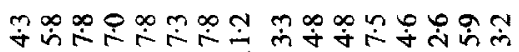

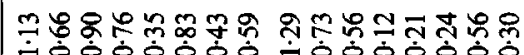

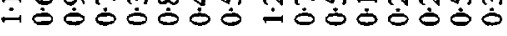
莺

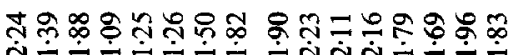
В

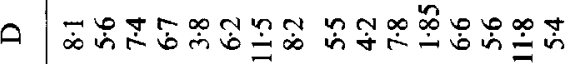

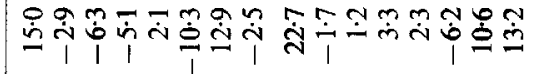

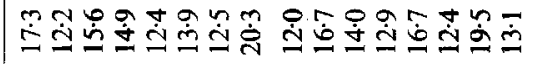

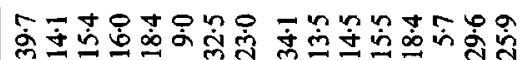

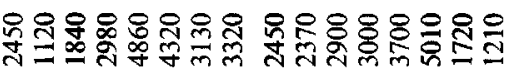

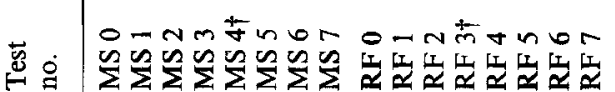
 
PROTEIN TURNOVER DURING ANTARCTIC CROSSING

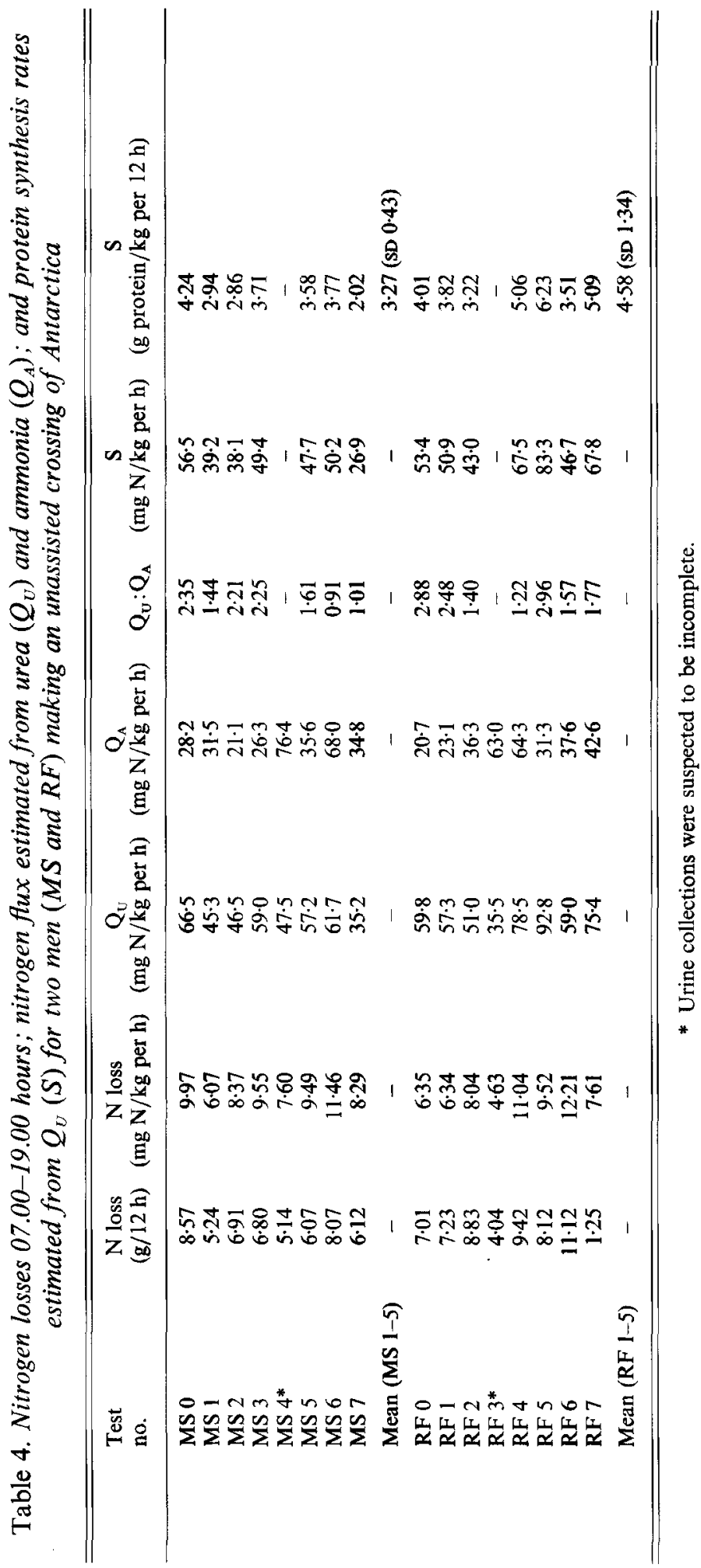


Under these conditions accurate collection, recording and storing of specimens is extremely difficult and collection of urine in the daytime even risked penile frostbite. It is, therefore, almost surprising that, as far as we can tell from the internal evidence, only two tests, one for each subject, had to be rejected because of losses of urine. This does not imply a large loss, but one that must have occurred at a critical time, soon after the dose of isotope had been given. The results must be examined with this in mind. However, because the men were constantly hungry during the expedition, there was essentially no plate wastage and with pre-weighed, pre-packed, simple daily rations, the estimates of dietary intake are likely to be very accurate.

During the course of the expedition, MS tended to be in negative apparent $\mathrm{N}$ balance, whereas RF tended to be in positive balance, although the outputs took no account of faecal and other losses. In principal, the amounts of urea, $\mathrm{NH}_{3}$ and other $\mathbf{N}$ sources excreted are irrelevant to the calculation of flux which depends only on ${ }^{15} \mathrm{~N}$ abundance in the end-products. However, the estimates of protein synthesis rates will have inaccuracies dependent on the additional $\mathbf{N}$ excreted and it is therefore of interest to examine the likely scale of such unaccounted $\mathbf{N}$ losses. The rates of change of lean tissue can be calculated from the body composition data and for the first $50 \mathrm{~d}$ there were losses of $4.9 \mathrm{~g} \mathrm{~N} / \mathrm{d}$ for MS and gains of $0.7 \mathrm{~g} \mathrm{~N} / \mathrm{d}$ for RF. These values are almost identical to the mean of the three values of apparent $\mathrm{N}$ balance for the same period (MS1-3, RF1-3) which gave losses of $4.8 \mathrm{~g} \mathrm{~N} / \mathrm{d}$ for MS and gains of $0.9 \mathrm{~g} \mathrm{~N} / \mathrm{d}$ for RF. This would suggest that non-urinary $\mathrm{N}$ losses during the period were very small, presumably due to efficient colonic salvage. For the second $45 \mathrm{~d}$ period the body composition data suggested a similar pattern of changes with losses of $0.8 \mathrm{~g} \mathrm{~N} / \mathrm{d}$ for MS and gains of $0.4 \mathrm{~g} \mathrm{~N} / \mathrm{d}$ for RF. However, in this case it would be misleading to make a comparison with the arithmetic mean of the two pertinent measurements (MS4 and 5, RF4 and 5), since the men reduced to half rations on day 84. Instead, a better mean for the latter $45 \mathrm{~d}$ period must be calculated by assuming that $\mathrm{N}$ balance during the $34 \mathrm{~d}$ up to day 84 was that measured in MS4 and RF4, while for $11 \mathrm{~d}$ beyond the switch to half rations it was that measured in MS5 and RF5. This approach gives mean losses of $0.9 \mathrm{~g} \mathrm{~N} / \mathrm{d}$ for MS and gains of $0.2 \mathrm{~g} \mathrm{~N} / \mathrm{d}$ for $\mathrm{RF}$, which are also remarkably close to the values derived from estimates of body composition changes.

These comparisons of $\mathrm{N}$ balance as assessed by two independent techniques suggest that non-accounted $\mathrm{N}$ losses must have been very small during the expedition. However, there must have been some additional losses via the gastrointestinal (GI) tract, the skin and nonmeasured urinary uric acid. GI losses of unabsorbed dietary $\mathbf{N}$ and other faecal losses normally range from $1-10 \%$ of dietary intake depending on the type of diet. In the case of this expedition the low intake of dietary fibre and the probability of enhanced colonic salvage would make it likely that GI losses were at the lower end of this scale and hence that less than $1 \mathrm{~g} \mathrm{~N} / \mathrm{d}$ was lost by this route. Skin losses are usually about $20 \mathrm{mg} \mathrm{N} / \mathrm{kg}$ body weight and so would amount to a maximum of $1.8 \mathrm{~g} \mathrm{~N} / \mathrm{d}$. The urinary losses accounted for in this study included those in urea, $\mathrm{NH}_{3}$ and creatinine, but not those in uric acid which may account for $3-5 \%$ of urinary $N$ for individuals on a diet of about $70 \mathrm{~g}$ protein/d. However, the actual amount of uric acid excreted does not normally rise with an increased protein intake and hence for the present subjects the value of $3 \%$ of urinary $\mathrm{N}$ losses being in this form would seem most likely. In this case maximal additional urinary $N$ losses would be of the order of $0.6 \mathrm{~g} / \mathrm{d}$. Overall, therefore, we believe that total unaccounted $N$ losses are unlikely to have exceeded $4 \mathrm{~g} / \mathrm{d}$ and would have led to overestimates of protein synthesis rates of only $5-10 \%$.

It is interesting that it was MS who was in apparent negative $\mathrm{N}$ balance from both bodycomposition studies and estimates of $\mathrm{N}$ intake and urinary losses. Garrow (1974) reported that when obese subjects lose weight through dietary restriction, approximately $25 \%$ of 
losses are lean, and hence energy deficits alone could have been responsible for the $10 \cdot 9 \%$ lean loss in MS. However, if this was the case one might have expected similar lean losses in RF. The dietary protein requirements for men undertaking endurance exercise of this nature are unclear. In a review, Lemon (1991) concluded that protein requirements in very active individuals may be as high as $160 \%$ of the recommended dietary allowance. However, he also noted that there is a decline in this exercise-induced protein requirement with continued training, and Millward et al. (1994) concluded that in fully trained individuals, $\mathbf{N}$ losses associated with physical activity are minimal. However, both these reviews assume that individuals are in energy balance and during this expedition this was not the case. It seems likely, therefore, that protein oxidation was needed to fuel exertion, particularly during moderate-to-high-intensity exercise when it is likely to have provided $5-10 \%$ of energy supply. Since MS, although much smaller, was pulling a sledge of equal weight to RF, the difference in $\mathrm{N}$ balance results might reflect the relatively higher exercise intensities at which MS must have worked for some of the journey.

Whatever the cause, the differences in $\mathrm{N}$ balance between the two men suggest that they behaved very differently in their metabolic responses to the stresses of the expedition and this individuality was also evident in the pattern of their $\mathrm{N}$ excretion. For example, MS excreted more $\mathrm{N}$ and more ${ }^{15} \mathrm{~N}$ in urea during the night than the day, whereas the opposite tended to be the case for RF. The $\mathrm{D}: \mathrm{N}$ ratios for creatinine were close to unity in both men, an observation that was also made during an expedition to the Andes, where day and night collections were made for $24 \mathrm{~d}$ (J. C. Waterlow, unpublished results). The $\mathrm{D}: \mathrm{N}$ ratios for ${ }^{15} \mathrm{~N}$ in $\mathrm{NH}_{3}$ were more varied but probably have little meaning, since far more $\mathrm{NH}_{3}$ is excreted by day and hence small fluctuations in night-time excretion have a big effect on ratios.

The main purpose of the present study was to examine how the basic biological process of protein turnover responded to conditions of extreme stress and negative energy balance imposed over a long period. There is evidence that acute physical exercise leads to an increase in body protein breakdown and a decrease in synthesis (e.g. Wolfe et al. 1984), but nothing is known about the effects of very-long-term exertion. In subjects exposed to infection or trauma, both components of protein turnover, synthesis and breakdown, are increased, with breakdown predominating to produce a negative $\mathrm{N}$ balance (Tomkins $e$ t al. 1983; Jeevanandam et al. 1986). On the food side, perhaps the best analogy is the severely malnourished child who for a long time has been short of energy and protein. In such children the rate of protein turnover is reduced (Waterlow, 1992). The Antarctic expedition provided a scenario in which all three of these elements affecting protein turnover were combined: intense exertion, some degree of infection and trauma, and food deficit.

The end-product method of measuring protein turnover with $\left[{ }^{15} \mathrm{~N}\right]$ glycine rests on a number of assumptions which have been justly criticized, but there is no other method that can be used in the field. The two estimates of flux that are obtained from the end-products urea and $\mathrm{NH}_{3}, \mathrm{Q}_{\mathrm{U}}$ and $\mathrm{Q}_{\mathrm{A}}$, are not additive, but are separate estimates of whole-body $\mathrm{N}$ flux. It is suggested that $Q_{U}$ is biased towards the metabolism in the splanchnic bed because urea is synthesized in the liver, whereas $Q_{A}$ is biased towards the peripheral tissues because the main source of glutamine, the precursor of urinary $\mathrm{NH}_{3}$, is probably the muscles. The ratio $Q_{V}: Q_{A}$ may, therefore, give us a glimpse of the relative rates of protein synthesis in these two parts of the body. Values obtained for this ratio in normal subjects are in the range 1.25-1.30 (Fern et al. 1981; Fern \& Garlick, 1983). In both RF and MS $Q_{U}: Q_{A}$, although variable, was almost always higher than this, and for the successful collection periods during the expedition it averaged 2.05 in RF and 1.87 in MS, perhaps indicating a relatively greater flux through the visceral organs with high protein feeding. Following the expedition, in recovery tests 6 and $7, Q_{U}: Q_{A}$ in $M S$ was well below the normal level, 
perhaps indicating that restoration of lost muscle was taking priority, although in RF low values were not seen at this time.

For the best estimate of total $\mathrm{N}$ flux it has been proposed that an average of $Q_{U}$ and $Q_{A}$, either arithmetic or harmonic, should be used (Fern \& Garlick, 1983; Fern et al. 1985a, b). However, since values of $Q_{A}$ in the present study were very variable, probably because $Q_{A}$ is subject to a number of influences such as changes in acid-base status, the synthesis rates given in Table 4 were derived only from $Q_{U}$. The mean values for protein synthesis in normal human subjects are between 2 and $3 \mathrm{~g}$ protein $/ \mathrm{kg}$ per $12 \mathrm{~h}$ (Fern et al. 1981; Fern $\&$ Garlick, 1983) and hence the values for the pre-expedition tests were markedly raised in both men, probably due to overfeeding, which might also account for the high values seen in the first post-expedition assessments. However, average values for the four successful measurements made during the course of the expedition were also higher than might have been expected at $3.3 \mathrm{~g}$ protein $/ \mathrm{kg}$ per $12 \mathrm{~h}$ for MS and $4.6 \mathrm{~g}$ protein $/ \mathrm{kg}$ per $12 \mathrm{~h}$ for RF, and we believe, therefore, that the overall message from these findings is that even in the face of great exertion, marked negative energy balance and serious physical deterioration, protein synthesis can be maintained. This indicates the vital role of protein synthesis in physiological function as long as life is not extinct.

\section{REFERENCES}

Brouwer, E. (1965). Report of sub-committee on constants and factors. In Energy Metabolism, pp. 441-443 [K. L. Blaxter, editor]. London: Academic Press.

Fern, E. B. \& Garlick, P. J. (1983). The rate of whole body metabolism in the whole body of man measured with ${ }^{15} \mathrm{~N}$ glycine and uniformly labelled ${ }^{15} \mathrm{~N}$ wheat. Human Nutrition: Clinical Nutrition 37C, 91-107.

Fern, E. B., Garlick, P. J., McNurlan, M. A. \& Waterlow, J. C. (1981). The excretion of isotope in urea and ammonia for estimating protein turnover in man with ${ }^{15} \mathrm{~N}$-glycine. Clinical Science 61, 217-228.

Fern, E. B., Garlick, P. J. \& Waterlow, J. C. (1985a). Apparent compartmentation of body nitrogen in one human subject: its consequences in measuring the rate of whole body protein synthesis with ${ }^{15} \mathrm{~N}$. Clinical Science 68 , 271-282.

Fern, E. B., Garlick, P. J. \& Waterlow, J. C. (1985 b). The concept of the single body pool of metabolic nitrogen in determining the rate of whole body nitrogen turnover. Human Nutrition: Clinical Nutrition 39C, 85-89.

Garrow, J. S. (1974), Energy Balance and Obesity in Man. Amsterdam: Elsevier and North Holland Press.

Grove, G. \& Jackson, A. A. (1995). Measurement of protein turnover in normal man using the end-product method with oral $\left[{ }^{15} \mathrm{~N}\right.$ lglycine: comparison of single-dose and intermittent-dose regimens. British Journal of Nutrition 74, 491-507.

Jeevanandam, M., Lowry, S. F., Horowitz, G. D., Legaspi, A. \& Brennan, M. F. (1986). Influence of increasing dietary intake on whole body protein kinetics in normal man. Clinical Nutrition 5, $41-48$.

Lemon, W. R. (1991). Does exercise alter dietary protein requirements? Advances in Nutrition and Top Sport 32, $15-37$.

Millward, D. J., Botwell, J. L., Pacy, P. \& Rennie, M. J. (1994). Physical activity, protein metabolism and protein requirements. Proceedings of the Nutrition Society 53, 223-240.

Stroud, M. A. (1987). Nutrition and energy balance on the "Footsteps of Scott" expedition 1984-86. Human Nutrition: Applied Nutrition 41A, 426-433.

Stroud, M. A. (1993). Shadows on the Wasteland-Crossing Antarctica with Sir Ranulph Fiennes. London: Jonathan Cape.

Stroud, M. A., Constantin-Teodosiu, D., Coward, W. A., Greenhaff, P. L., Ritz, P. \& Sawyer, M. B. (1996). Energy expenditure using isotope-labelled water $\left({ }^{2} \mathrm{H}_{\mathrm{a}}{ }^{18} \mathrm{O}\right)$, exercise performance, skeletal muscle enzyme activities and plasma biochemical parameters in man during 95 days endurance exercise with inadequate energy intake. European Journal of Applied Physiology (In the Press).

Tomkins, A. M., Garlick, P. J., Schofield, W. N. \& Waterlow, J. C. (1983). The combined effects of infection and malnutrition on protein metabolism in children. Clinical Science 65, 313-324.

Waterlow, J. C. (1992). Protein -energy Malnutrition, p. 93. London: Edward Arnold.

Waterlow, J. C., Garlick, P. J. \& Millward, D. J. (1978a). Protein Turnover in Mammalian Tissues and in the Whole Body. Amsterdam: North Holland.

Waterlow, J. C., Golden, M. H. J. \& Garlick, P. J. (1978b). Protein turnover in man measured with ${ }^{15}$ N: comparison of end products and dose regimes. American Journal of Physiology 4, E165-E174.

Wolfe, R. R., Wole, M. H., Nadel, E. R. \& Shaw, J. H. F. (1984). Isotopic determination of amino acid-urea interactions in exercise in humans. Journal of Applied Physiology 56, 221-229. 